\title{
CONDITIONS RELATING TO THE TREATMENT OF EMPLOYÉS AND LABORERS IMPOSED BY THE CITY OF PARIS UPON THE COMPANY TO WHICH THE METROPOLITAN ROAD WAS LEASED.
}

By a law passed March 30 , I898, the city of Paris was authorized to proceed with the construction of a system of underground railway lines, to be known as the Metropolitan Railway and to be operated by electricity.

The city was permitted to excavate the tunnels, make the cuttings, and build the viaducts - at the point where the railway emerges from the ground, as it will in one or two places. It is not permitted, however, to lay the tracks or work the road. This part of the enterprise must be intrusted to a working company, which is to lay the tracks, construct the electric plant and stations, and operate the road. The city receives, roughly speaking, one-third of the gross income from the sale of tickets, as rent for the part of the road which it constructs and for the right-of-way. The company takes two-thirds for its portion.

One section of the road, completing about one-sixth of the entire system, is almost completed, and is expected to be in operation by June $\mathrm{I}$.

The conditions which the city imposed upon the company in regard to the treatment of its laborers and employés are extremely interesting, and indicate the high-water mark attained by modern cities in this respect.

The more important of these conditions are contained in the following provisions, of Articles XVIII and XIX of the agreement between the city and the traction company:

Article XVIII. The working of the leased lines shall be organized in a manner to comply with the following provisions :

1. The salaries or wages of the workmen and employés shall be paid fortnightly, and shall in no case be less than I 50 francs per month. Men employed temporarily shall receive wages which shall not be lower than 5 francs per day.

2. The working day shall not exceed ten hours. One full day of rest or two full half-days shall be granted each week to the personnel.

3. An annual vacation of ten days, with full salary, shall be granted to all employés.

4. The full salary shall be paid during the periods of military instruction.

5. Days of sickness, properly certified by the physician appointed by the managers of the fund established in accordance with Article XIX below, shall be paid for in full, without any deduction, during the period of at least one year. 
6. In case of accident happening during work and resulting in a temporary incapacity, the workmen shall receive their entire wages until complete recovery, without prejudice to the indemnity which shall be due to them in case of final disability, either total or partial.

7. The workmen employed in the enterprise shall be insured against accident at the sole cost of the leasing company, which shall not under this head make any deductions from the wages due. Moreover, whatever may be determined in regard to the responsibility for an accident, the leasing company shall always be directly responsible to the victim for the payment of the indemnity.

A physician appointed by the management of the special fund, established in accordance with Article XIX below, shall be summoned to report upon each accident, and it shall be his duty to state the nature and the results of the same.

8. The administration of the city shall always have the right to prescribe such measures of safety and health as may be considered necessary.

9. A written commission shall be delivered, under the form of a wage contract, to every adult employé or workman, of either sex, who may have completed twenty-four months of service.

The leasing company is required to observe strictly the conditions above enumerated, in regard to the labor of its employés, under penalty of forfeiture of the lease.

Article XIX. The leasing company binds itself further:

(a) To furnish to the working personnel in its employ deposit books of the National Pension Fund. The payments shall be made by means of a 2 per cent. deduction from the wages of the employés and a 4 per cent. contribution by the company, making 6 per cent., which shall be deposited in their name by the leasing company, on the conditions defined below.

However, whenever the number of passengers shall exceed 220,000,000, the deduction from the wages of the laborers shall be reduced to $\mathrm{I}$ per cent., and the contribution by the company increased to 6 per cent., thus making the payment to be made in their name by the leasing company 7 per cent.

(b) To establish a free medical and drug service.

(c) To insure its laborers and employés against accidents.

To insure the execution of paragraph $(b)$ of the present article, as well as paragraphs 5,6 , and 7 of the preceding article, the leasing company shall organize a special fund, which shall be managed by the workmen and employés themselves.

The leasing company shall charge to general expenses a sum sufficient to make the payments stipulated in $(a),(b)$, and $(c)$.

It is an interesting fact that the introduction of these provisions into the lease did not give rise to any prolonged negotiations between the parties concerned, nor did it excite any considerable discussion either in the city council 
or the Parliament. In fact, the leasing company agreed readily to all the conditions, and indeed proposed itself some of the clauses favorable to the laborers.

PARIS,

Edmund J. James.

March I7, I900.

The day after dictating above note Professor James mailed the following addition :

I find that the government, upon the demand of the minister of public works and upon the advice of the council of state, has struck out the two provisions of the lease relating to the minimum wage and the normal working day. This makes a material change, of course, in the actual facts concerning the provisions for the benefit of the laborers; but it leaves undisturbed the significance of the circumstance that the city had insisted upon the insertion of this provision, while the leasing company had accepted it without any protest. The government struck out these clauses on the ground that they referred to matters already regulated by provisions in the existing code, and that these provisions should be altered only by general law and not by special contract.

E. J. J. 